\title{
Adaptasi Pola Ritme Dangdut pada Ansambel Perkusi
}

\author{
Agus Salim* \\ Jurusan Musik, Fakultas Seni Pertunjukan, Institut Seni Indonesia Yogyakarta
}

\begin{abstract}
Dangdut Rhythmic Pattern Adaptation on Percussion Ensamble. This article discuss the adaptation process of "Dangdut" rhythmic pattern and its tone qualities that were implemented in to the percussion ensemble. Earlier studies showed that bath elements can pessibly be tone. It means that the differences between characteristic music basically can be used as a new musical idea to produce a new genre of music. This procedure began with the implementation of new special symbol to be fitted in to the western notation; it follows by the selection of "Dangdut" rhythmic pattern and to be implemented in to the percussion ensemble instruments such as timpani, bongo, hi-hat, roto-toms and tambourine. The result was a new color of musical genre that gives a new propective and possibility in the world of music composition.
\end{abstract}

Keyword : music adaptation, rhythmic pattern, dangdut.

\section{Pendahuluan}

Ritme merupakan elemen waktu dalam musik yang dihasilkan dari durasi serta aksen. Pola ritme adalah salah satu aspek dari struktur dasar musik yang meliputi antara lain batteri rhythmic, tone color, acent. Pola ritme merupakan salah satu wujud sebagai pedoman cara memainkan struktur ritme dari keseluruhan aspek ritme yang bersifat komplek. Pola ritme dapat dimainkan sendiri tetapi dapat pula dimainkan bersama-sama dengan alat musik lainnya, bahkan dari wujud pola ritme dapat ditebak atau dimengerti secara keseluruhan penyajian musik baik gaya, jenis musiknya, seperti pola ritme swing, bosanova, blues, keroncong, termasuk pola ritme dangdut.

Dangdut merupakan salah satu dari genre seni musik yang berkembang di Indonesia. Bentuk musik ini berakar dari musik Melayu pada tahun 1940-an. Dalam evolusi menuju bentuk kontemporer sekarang masuk pengaruh unsurunsur musik India (terutama dari penggunaan tabla) dan Arab (pada cengkok dan harmonisasi). Perubahan arus politik Indonesia di akhir tahun 1960-an membuka masuknya pengaruh musik barat yang kuat dengan masuknya penggunaan gitar listrik dan juga bentuk pemasarannya.

Sejak tahun 1970-an dangdut boleh dikatakan telah matang dalam bentuknya yang kontemporer. Sebagai musik populer, dangdut sangat terbuka terhadap pengaruh bentuk musik lain, mulai dari keroncong, langgam, degung, gambus, rock, pop, bahkan house music. Penyebutan nama "dangdut" merupakan onomatope dari suara permainan tabla (dalam dunia dangdut disebut gendang saja) yang khas dan didominasi oleh bunyi dang dan ndut. Nama ini sebetulnya adalah sebutan sinis dalam sebuah artikel majalah awal 1970-an bagi bentuk musik melayu yang sangat populer di kalangan masyarakat kelas pekerja saat itu.

Musik dangdut sudah menjadi milik masyarakat luas, hingga sekarang masih digemari khususnya dikalangan anak muda. Untuk itu perlunya musik dangdut dijaga dan dilestarikan keberadaannya agar tidak mudah punah. Dengan terus mengembangkan melalui berbagai bentuk kreativitas yang nantinya dapat dijadikan referensi, salah satunya yakni mengadaptasikan atau mengimplementasikan musik dangdut pada ansambel musik perkusi.

Ansambel musik perkusi (barat); ansambel disini merupakan salah satu istilah, yakni sekelompok pemain musik yang bermain bersama-sama secara tetap. Sedangkan perkusi itu sendiri berasal dari kata percussion, berarti nama alat-alat musik pukul, dalam kepentingannya dapat melahirkan irama atau peralihan irama. (Ensiklopedi Musik: 1992). Dengan demikian yang dimaksud dengan

\footnotetext{
*Alamat korespondensi: Prodi Musik, FSP ISI Yogyakarta, jalan Parangtritis Km. 6,5 Sewon, Bantul, Yogyakarta-55001. E-mail: agusalim@isi.ac.id.
} 
ansambel perkusi adalah sebuah permainan oleh sekelompok pemain musik dengan menggunakan alat-alat musik pukul. Berdasarkan jenisnya, alat-alat musik perkusi (barat) ada dua yaitu (1) perkusi ritmis (infinded); yakni alat musik perkusi tidak bernada seperti snare drum, bas drum, tom-tom, bongo, conga, cymbal, bell chimes, triangle, cow bell, tambourine dan lain sebagainya. (2) perkusi melodis (finded); yakni alat musik perkusi yang bernada seperti marimba, xylophone, vibraphone,chimesi dan lain sebagainya. Alat-alat perkusi tersebut memiliki peranan sangat penting dan saling mendukung satu sama lain, sebagai permainan tunggal, kelompok (ansambel).

Apabila disimak kehidupan musik baik ragam, jenis, gaya dan bentuk musik memiliki kesamaan dalam pertumbuhannya karena factor-faktor, seperti lingkungan alam (kodrat) dan zaman (masyarakat). Sehingga pertemuan musik antara tradisi, diatonis, maupun kebudayaan yang ada dinegara ini, bangsa, induk, ras di seluruh dunia tentu akan menghasilkan akulturasi. Artinya dua atau lebih jenis, gaya, bentuk musik dapat hidup berdampingan atau asimilasi yakni salah satu dari jenis, gaya, bentuk musik di dalam pertemuannya ada yang tetap hidup dan lainnya mati atau sintesa. Artinya pertemuan dari dua atau lebih jenis, gaya, bentuk musik tersebut mampu melahirkan bentuk musik baru.

\section{Proses Adaptasi}

Proses adaptasi ini merupakan penggunaan idiom-idiom musik dangdut yang akan diwujudkan dalam sebuah komposisi ansambel musik perkusi. Beberapa kemungkinan yang ada, baik secara analisis maupun perancangan memberikan kemungkinan proses Adaptasi Pola Ritme Dangdut pada Ansambel Perkusi dapat dilakukan. Dalam proses adaptasi kemungkinan akan mengalami penggeseran khususnya dalam segi gaya maupun warna suara instrument perkusi. Namun demikian, melalui perancangan dengan menggunakan idiom-idiom musik dangdut pada ansambel perkusi ini akan menghasilkan sebuah komposisi musik baru yang dapat diapresiasikan pada masyarakat luas.

\section{Pembahasan}

\section{Bentuk Pola Ritme Dangdut}

Bentuk pola ritme dangdut sangat berfariasi, tetapi secara ritme dasar tidak berubah yang berubah hanya tempo, aksentuasi dan warna nada. Oleh sebab itu agar lebih mengarah dalam proses adaptasi ini perlu adanya batasan-batasan, beberapa bentuk pola ritme yang

ada akan diseleksi dan selanjutnya dianggap dapat mendukung dalam pembuatan komposisi ansambel musik perkusi. Adapun bentuk pola ritme dangdut adalah sebagai berikut;

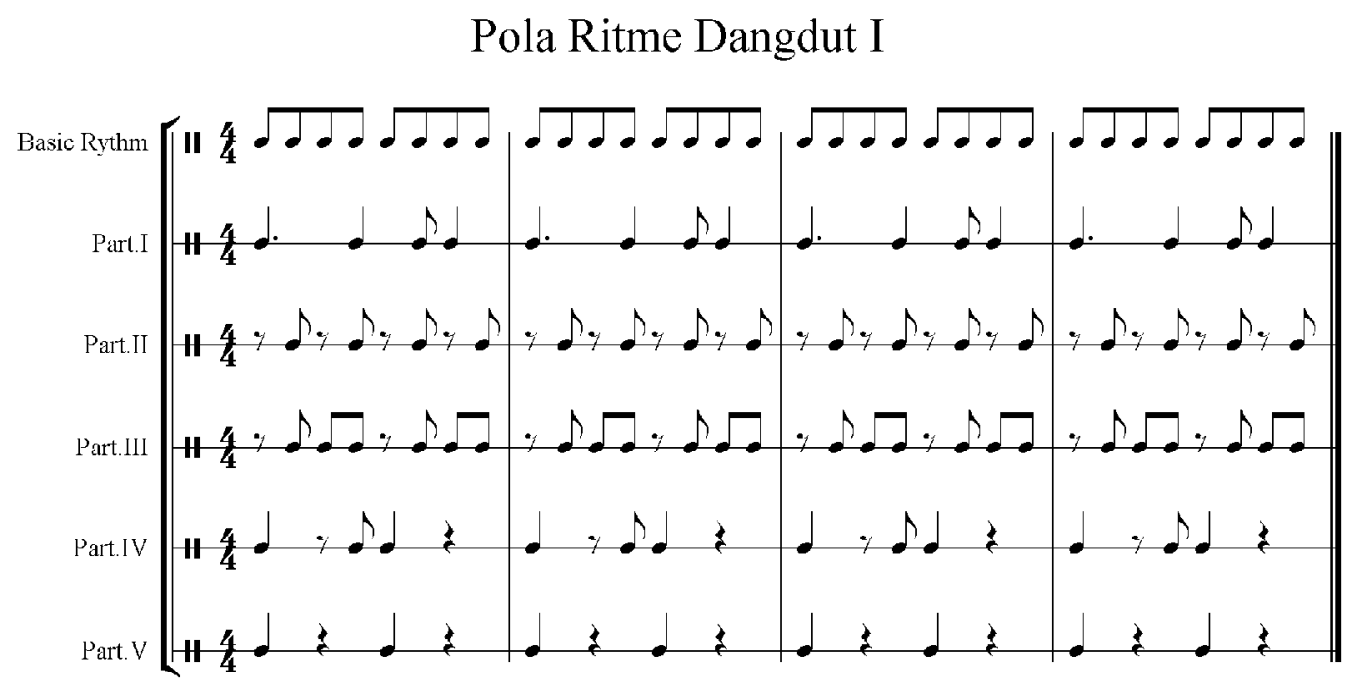


Pola Ritme Dangdut II

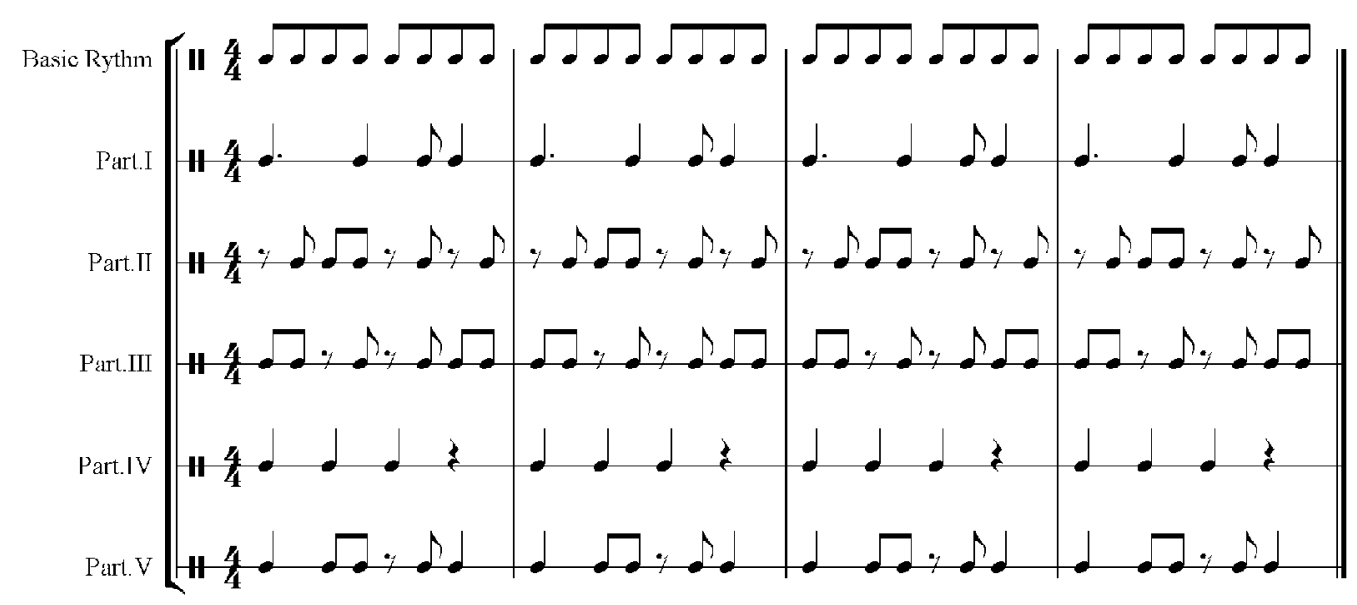

Pola Ritme Dangdut III

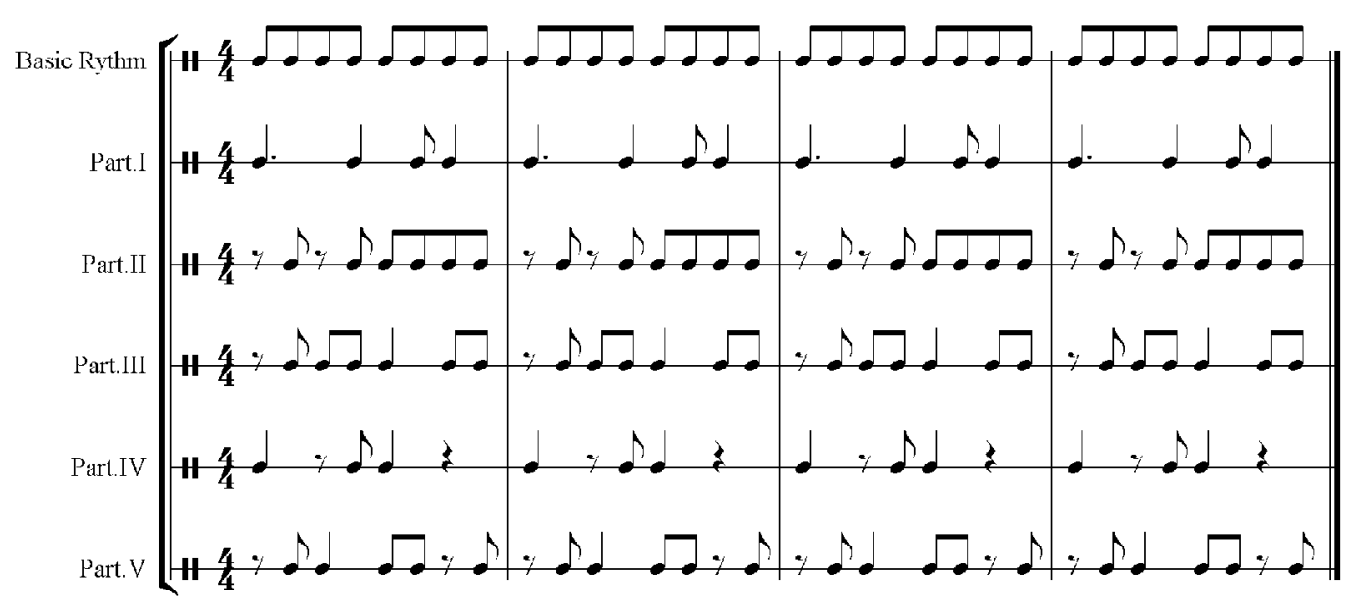

Pola Ritme Dangdut IV

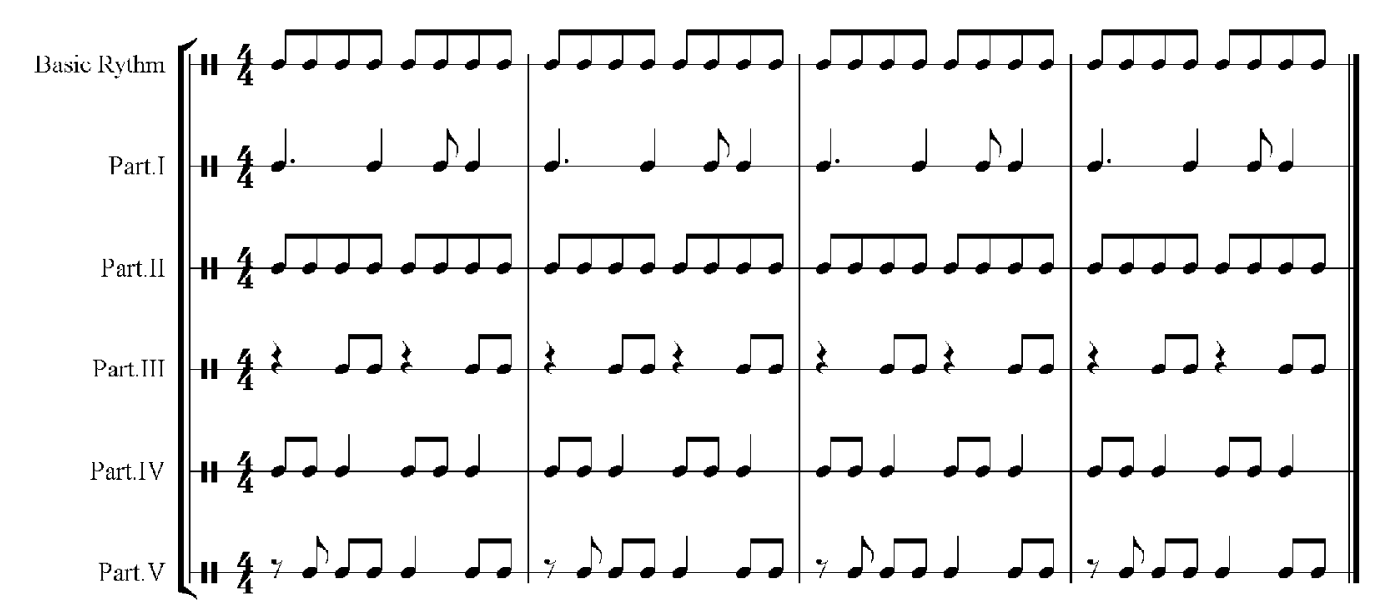




\section{Teknik Adaptasi}

Adaptasi dimaksud disini adalah pola ritme dangdut diimplementasikan pada alat-alat musik perkusi Barat antara lain seperti; bongo, roto-tomt, tamborin, hi-hat, timpani yang dikemas dalam bentuk ansambel musik perkusi.

Sebagai langkah awal dalam adaptasi ini, pentingnya beberapa alat musik perkusi seperti bongo,roto-tom dan timpani di stem atau ditala untuk dicari warna suaranya yang paling dekat dengan suara aslinya. Dalam segi suara alat-alat musik perkusi tersebut memiliki sifat atau karakter yang berbeda antara satu dengan lainnya, sehingga terdapat cirri khas dan peranannya dapat berfungsi demuikian. Selanjutnya empat macam pola ritme dangdut tersebut diatas adalah pola ritme dangdut I terdiri dari enam staf atau part yakni staf pertama atau ritme dasar (basic rhytm) terdiri dari 2 birama dengan sukat/birama 4/4 dan mempunyai nilai nada seperdelapanan, sedangkan staf / part 1 juga terdiri dari 2 birama dengan sukat/birama $4 / 4$ adalah merupakan pengembangan dari ritme dasar yang sudah ada, untuk part 2 juga merupakan pengembangan dari ritme dasar yang terdiri dari 2 birama dengan menggunakan tanda sukat/birama 4/4, kemudian pada part 3 terdiri dari 2 birama dengan menggunakan tanda sukat/birama $4 / 4$ juga merupakan pengembangan dari ritme dasar yang sudah ada, untuk part 4 juga terdiri dari 2 birama dan menggunakan tanda sukat/birama 4/4 merupakan pengembangan dari ritme dasar yang sudah ada, sedangkan pada part 5 terdiri dari 2 birama dengan menggunakan tanda sukat/birama 4/4 juga merupakan pengembangan dari ritme dasar yang sudah ada. Pola ritme dangdut tersebut masing-masing staf / part akan diadaptasikan pada 5 alat musik perkusi seperti timpani, hi-hat, bongo, roto-toms dan tambourine, dan setiap pola ritme dadibagi menjadi dua kelompok yakni basic pulse (timpani, hi-hat dan tambourine) dan solo attack ( bongo dan roto-toms). Sebagai langkah selanjutnya adalah pola ritme dangdut I yaitu terdiri dari part I diadaptasikan pada timpani, dan untuk part 2 diadaptasikan pada hi-hat, sedang untuk part 3 diadaptasikan pada bongo, dan part 4 akan diadaptasikan pada roto-toms, sedangkan part 5 diadaptasikan pada tambourine.

Berikut merupakan hasil adaptasi yang berbentuk score atau partitur komposisi ansambel musik perkusi yang berjudul "DANGDUTAN". Secara analisis akan dijabarkan pengertianpengertian teoritis yang dianggap relevan untuk pendekatan dalam analisis ini, salah satu diantaranya adalah ritme merupakan unsur dasar yang dianggap penting dalam pembuatan sebuah komposisi musik.

Komposisi musik ini terdiri dari dari beberapa bentuk pola ritme. Dimulai 5 birama pertama yang disebut sebagai introduksi, yakni merupakan bentuk yang akan mengawali komposisi ansambel musik perkusi. Introduksi ini apabila dimainkan dengan membaca tanda ulang maka jumlahnya menjadi 8 birama.Tanda sukat / birama pada komposisi ini adalah 4/4 artinya setiap birama terdiri dari empat ketukan dan mempunyai nilai nada 1/4 dan menggunakan tada tempo allegro yang artinya cepat. Komposisi ini di awali dengan sebuah melodi pendek yang dimainkan oleh cimbalom, dulcimer, zither, steel drum, xylophone, marimba dan vibraphone secara bersama (unisono ) serta menggunakan dinamika fortesimo (f) yang artinya keras, yakni mulai birama gantung (opmaat) kemudian masuk birama 1 sampai dengan birama 4 (kamar 1) kemudian diulang kembali dari birama 1 sampai birama 3 terus masuk kamar 2. Sedangkan pola ritme dangdut pada introduksi ini dimainkan oleh alat-alat perkusi seperti timpani, hi-hat, bongo, roto-toms, dan tambourine dengan menggunakan dinamika mezzo forte $(m f)$ artinya agak keras yakni mulai dari birama 1 sampai dengan birama 4 (kamar 1) kemudian diulang kembali dari birama 1 sampai birama 3 dan terus masuk kamar 2 . 
Agus Salim, Adaptasi Pola Ritme Dangdut pada Ansambel Perkusi

DANGDUTAN

Agus Salim
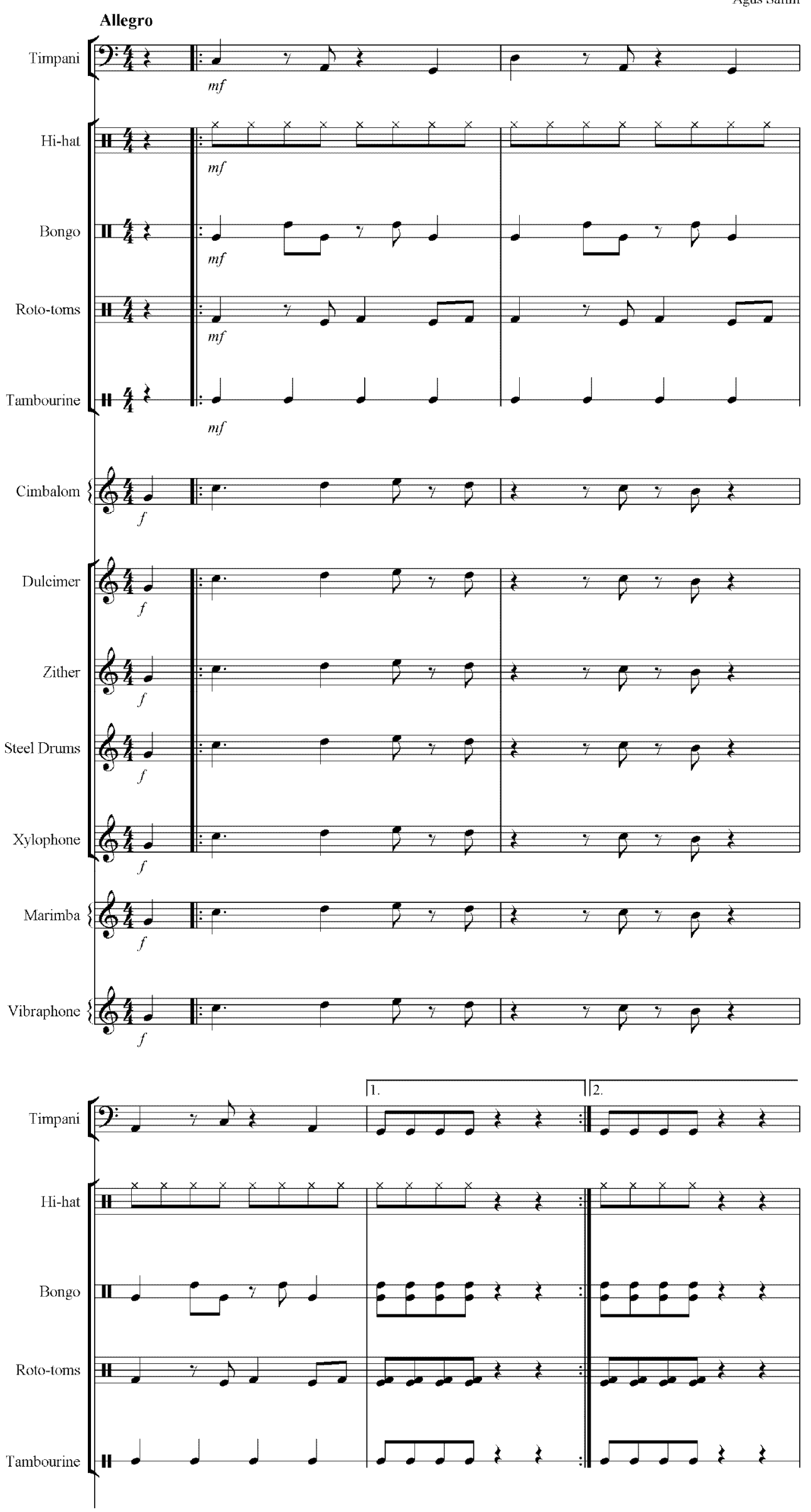

110 
Resital Vol. 11 No. 2, Desember 2010
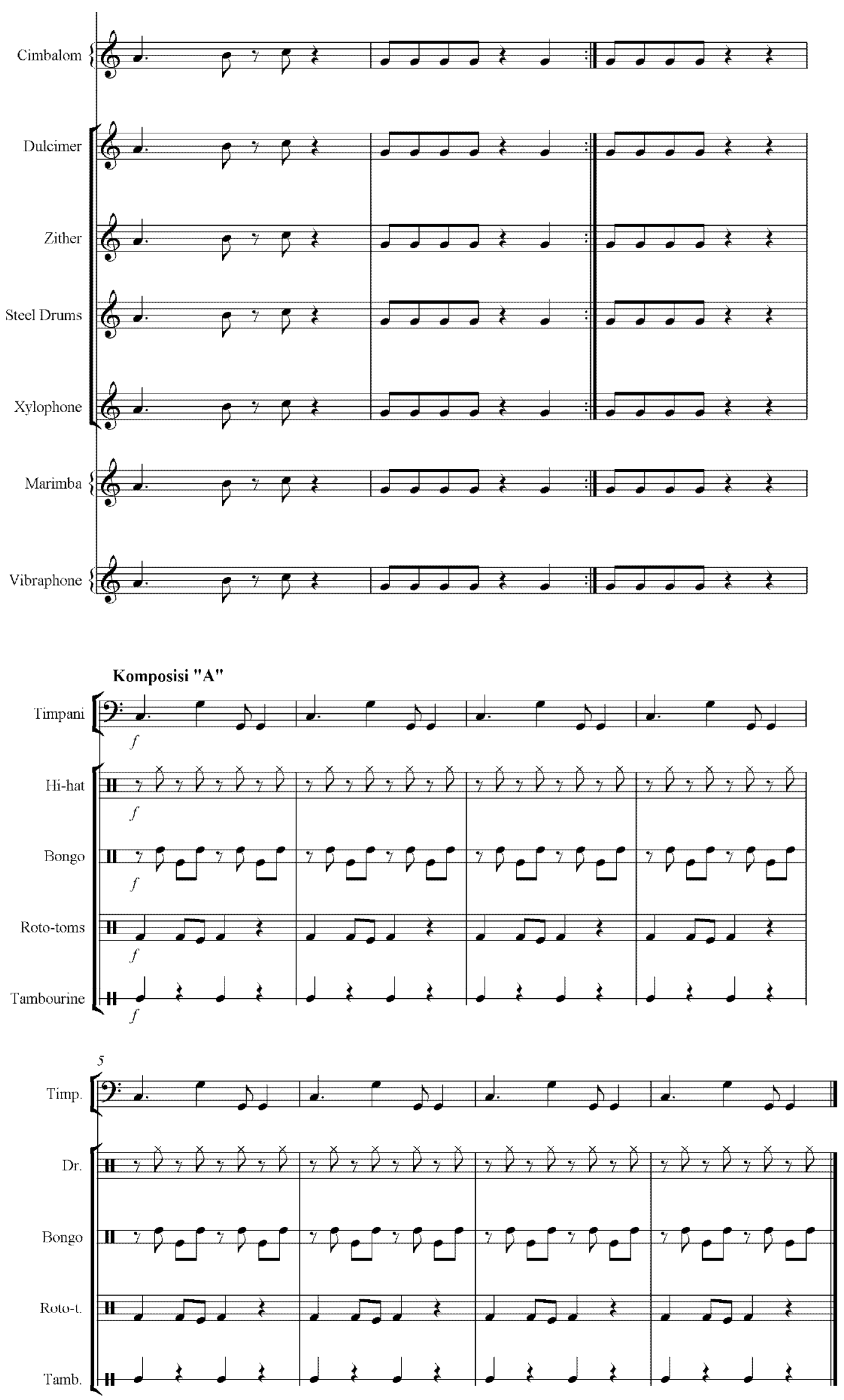

111 
Pada birama berikutnya disebut bentuk komposisi A berjumlah 8 birama dengan menggunakan tanda sukat/birama $4 / 4$ yakni setiap birama terdapat empat ketukan dan masing-masing mempunyai nilai nada seperempatan. Sedangkan tanda temponya adalah allegro yang artinya cepat. Komposisi ini merupakan hasil adaptasi dari bentuk pola ritme dangdut 1 yakni terdiri dari part.1 diadaptasikan pada timpani, bentuk pola ritmenya dari birama 1 sampai dengan birama ke 8 dimainkan sama dan menggunakan dinamika fortesimo (f) yang artinya keras, untuk part.2 diadaptasikan pada hi-hat, bentuk pola ritmenya (sincope) dari birama 1 sampai birama 8 sama dan dimainkan dengan suara keras (fortesimo), berikutnya adalah part. 3 diadaptasikan pada bongo, bentuk pola ritmenya dari birama 1 sampai 8 sama dan dimainkan dengan suara keras (fortesimo), untuk part. 4 diadaptasikan pada roto-toms, bentuk pola ritmenya sama yaitu dari birama 1 sampai birama ke 8 dan dimainkan dengan suara keras (fortesimo), dan untuk part. 5 akan diadaptasikan pada tambourine, bentuk pola ritmenya dari birama 1 sampai birama 8 adalah sama dan dimainkan dengan suara keras (fortesimo).. Pola ritme dangdut 1 atau komposisi A ini dikelompokkan menjadi 2 macam yakni kelompok basic pulse ( timpani, hi-hat dan tambourine) dan solo attack (bongo, roto-toms dan tambourine)

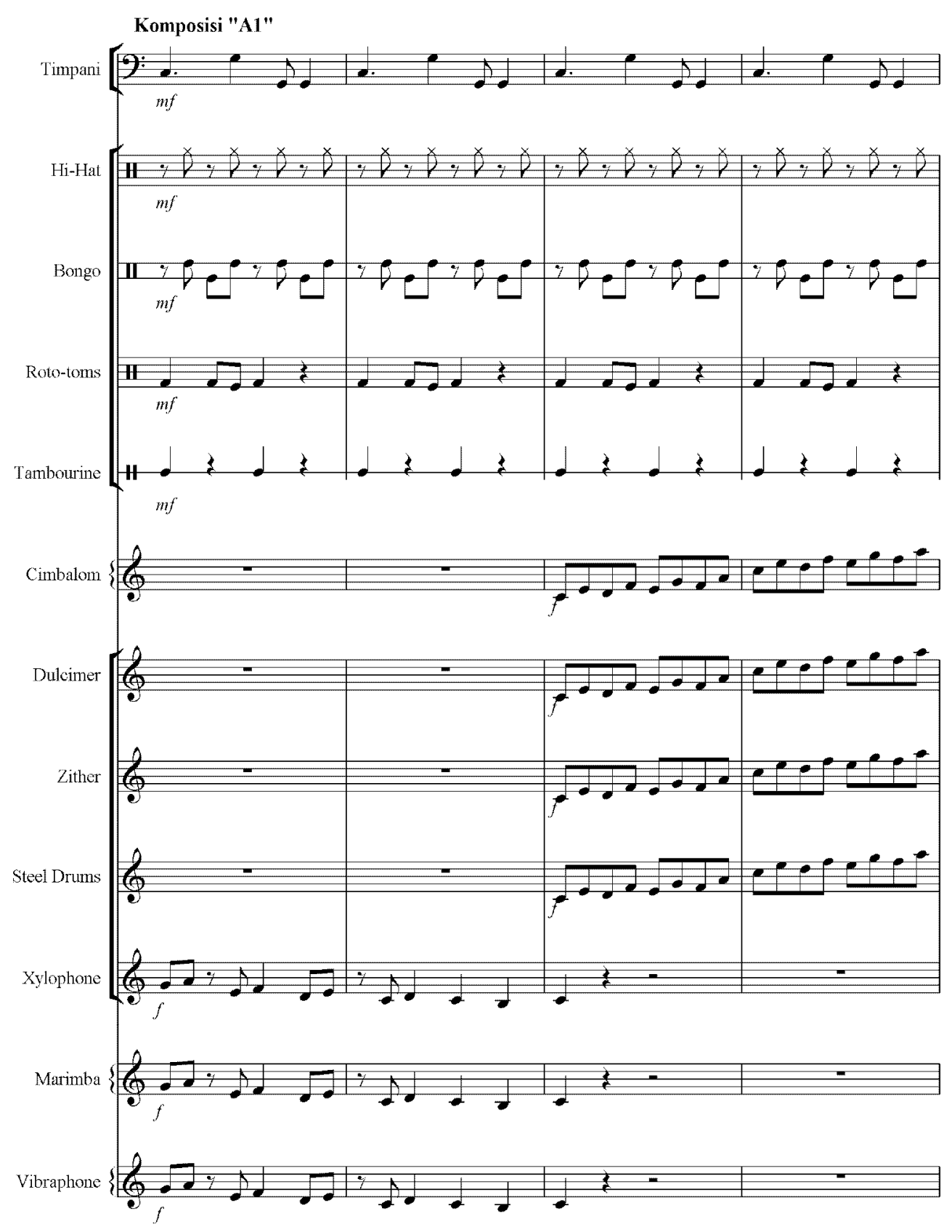




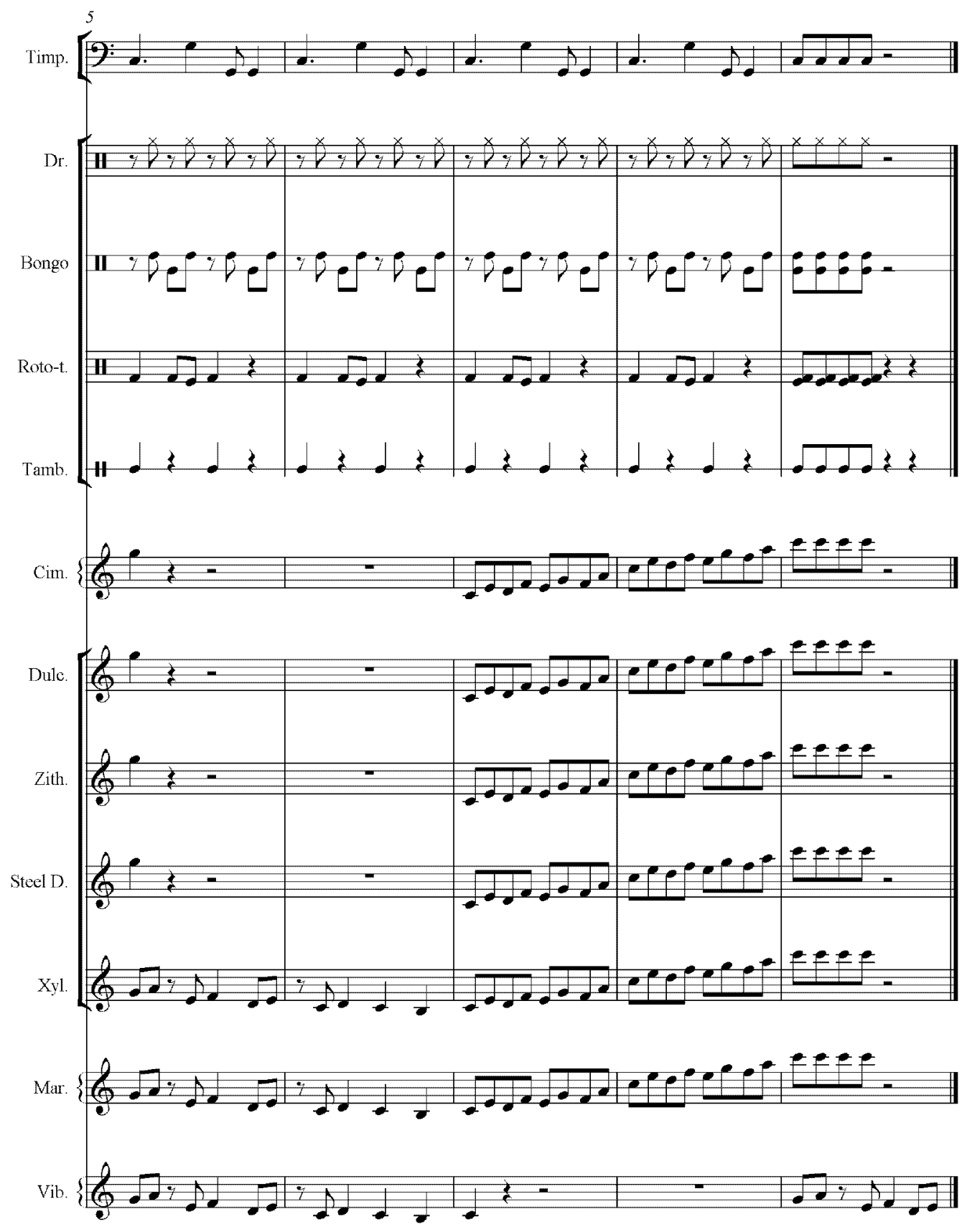

Pada komposisi A1 terdiri dari 9 birama dengan menggunakan tanda sukat/birama 4/4 yakni setiap birama terdapat empat ketukan dan nilai nadanya adalah seperempatan. Untuk temponya adalah allegro yang artinya cepat. Bentuk pola ritme pada komposisi A1 sama seperti pada komposisi A, yakni birama 1 samapai 8 merupakan hasil adaptasi dari bentuk pola ritme dangdut 1 , masing-masing part diadaptasikan pada 5 alat musik perkusi seperti timpani, hi-hat, bongo, roto-tom dan tambourin dengan menggunakan dinamika mezzo forte. Pada komposisi A1 selain menggunakan alat-alat perkusi yang bersifat ritmis juga terdapat alat-alat perkusi melodis seperti cimbalom, dulcimer, zither, steel drum, xylophone dan marimba serta vibraphone. Di birama 1 sampai 3 muncul sebuah melodi pendek dimainkan oleh xylophone, marimba dan vibraphone secara bersama-sama (unisono) dengan menggunakan dinamika fotesimo yang artinya keras, kemudian di birama 3 sampai 5 terdapat melodi baru yang dimainkan oleh cimbalom,dulcimer, zither dan steel drum secara bersama-sama (unisono) dengan menggunakan dinamika yang sama, di birama 
5 samapi 7 xylophone, marimba dan vibraphone kembali memainkan melodi pendek dan berikutnya di birama 7 sampai 9 semua alat musik perkusi melodis memainkan melodi pendek secara bersama-sama (unisono) dengan menggunakan dinamika fortesimo.
Komposisi B ini terdiri dari 8 birama dengan menggunakan tanda sukat/birama $4 / 4$ yaitu setiap birama terdiri dari empat ketukan dan masingmasing ketukan nilai nadanya seperempatan. Tanda tempo pada komposisi ini adalah allegro

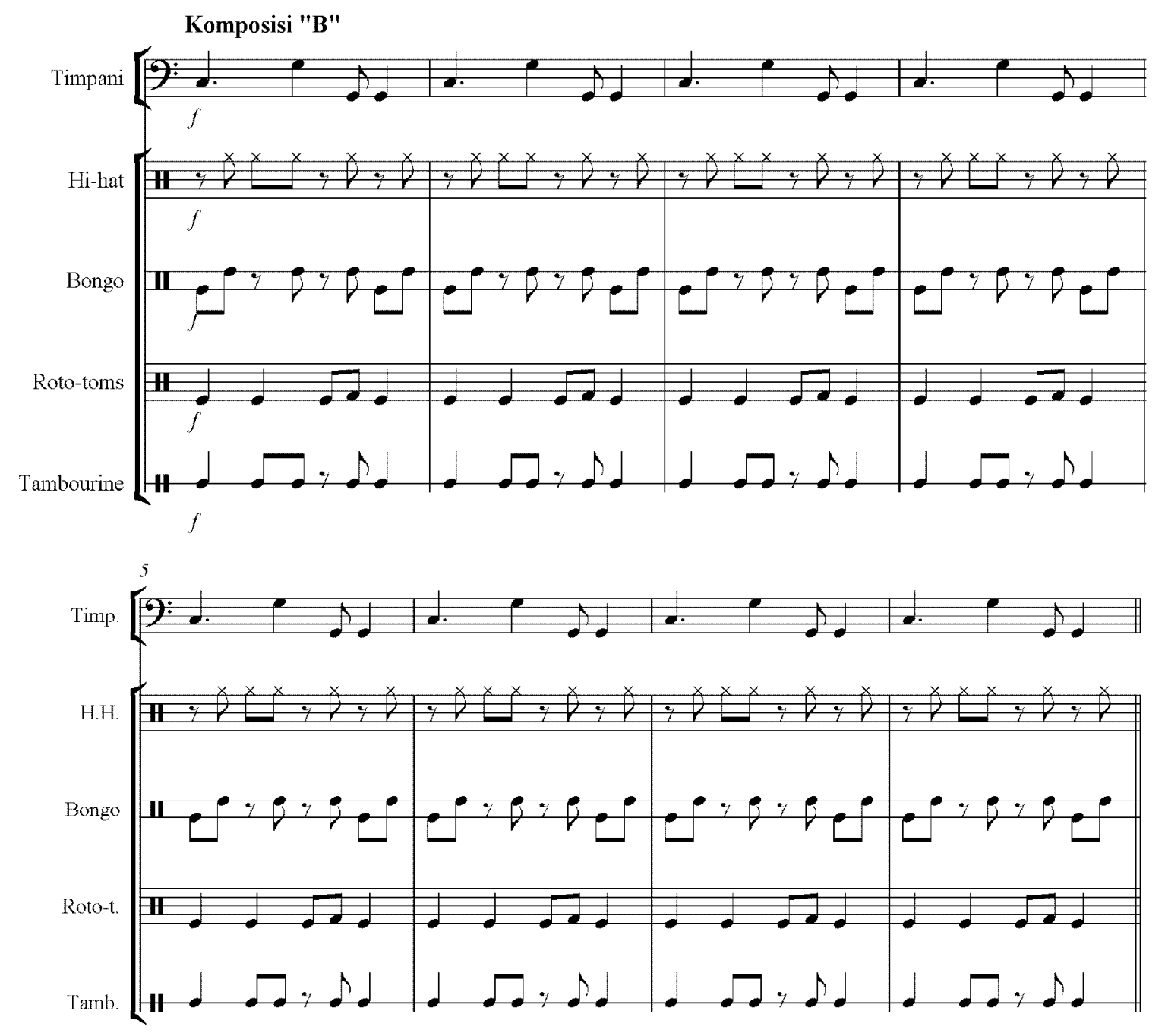

yang artinya cepat. Bentuk komposisi ini merupakan hasil adaptasi dari pola ritme dangdut 2 yakni terdiri dari part 1 diadaptasikan pada timpani, bentuk pola ritmenya dari birama 1 sampai dengan birama 8 dimainkan sama dan menggunakan dinamika fortesimo $(f)$ yang artinya keras, untuk part 2 akan diadaptasikan pada hi-hat, bentuk pola ritmenya dari birama 1 sampai dengan birama 8 dimainkan sama dan menggunakan dinamika fortesimo (f) yang artina keras, kemudian part 3 diadaptasikan pada bongo, bentuk pola ritmenya dari birama 1 sampai dengan birama 8 dimainkan sama dan dinamikanya juga keras, sedangkan untuk part 4 dan 5 masing-masing diadaptasika pada roto-tom dan tambourine, bentuk pola ritmenya dari birama 1 sampai dengan birama 8 dimainkan sama dan dengan dinamika fortesimo (f) yang artinya keras. Pola ritme dangdut 2 atau komposisi B ini dibagi menjadi 2 kelompok yakni basic pulse (timpani, hi-hat dan tambourine) dan solo attack (bongo dan roto-tom).

Komposisi B1 terdiri dari 9 dengan menggunakan tanda sukat/birama 4/4 yaitu setiap birama mempunyai empat ketukan dan nilai nadanya adalah seperempatan, serta menggunakan tanda tempo allegro yang artinya cepat. Bentuk pola ritme B1 sama seperti pada komposisi B yakni birama 1 sampai 8 merupakan hasil adaptasi dari 
Resital Vol. 11 No. 2, Desember 2010
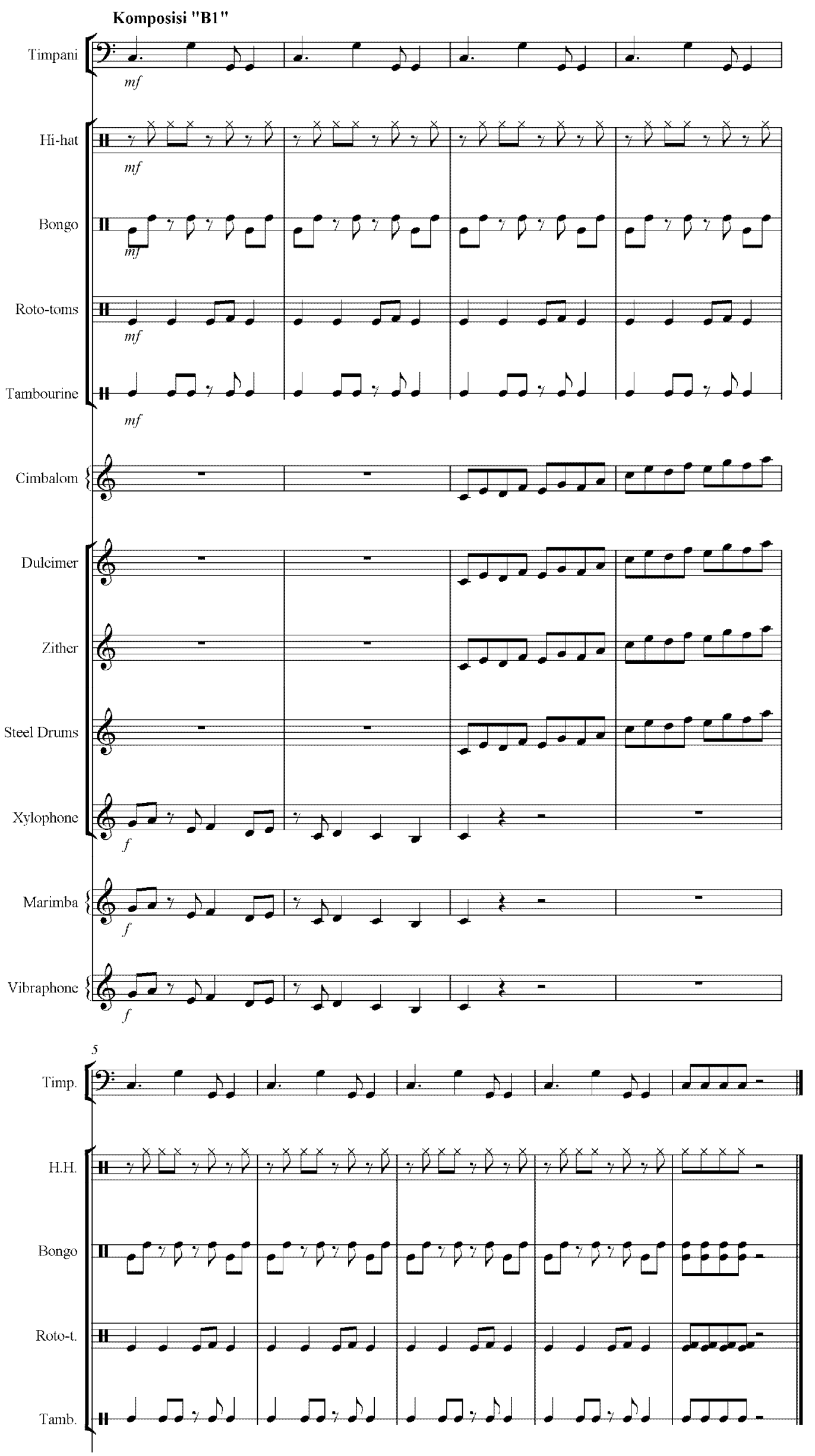

115 


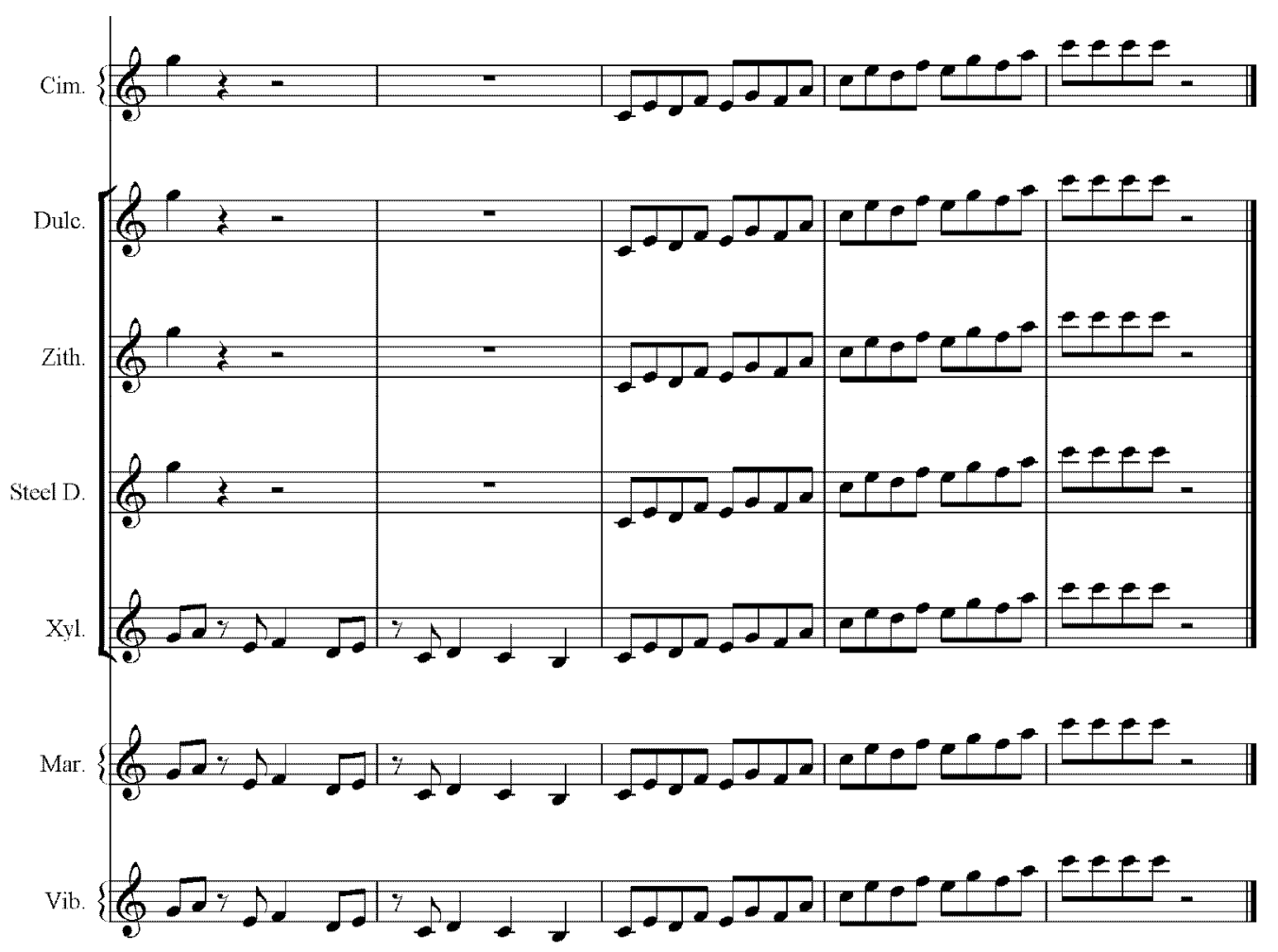

bentuk pola ritme dangdut 2, masing-masing part diadaptasikan pada 5 alat musik perkusi seperti timpani, hi-hat, bongo, roto-tom dan tambourine dengan dinamika agak keras ( mezzo forte). Pada komposisi B1 selain menggunakan alat-alat musik perkusi yang bersifat ritmis juga terdapat alat-alat perkusi melodis seperti cimbalom, dulcimer, zither, steel drum, xylophone, marimba dan vibraphone. Di birama 1 sampai 3 muncul sebuah melodi pendek yang dimainkan oleh xylophone, marimba dan vibraphone secara bersama-sama (unisono) dimainkan dengan keras ( fortesimo), kemudian dibirama 3 sampai 5 terdapat melodi baru yang dimainkan oleh cimbalom, dulcimer, zither dan steel drum secara bersama-sama (unisono) juga dimainkan dengan keras ( forte) dan dibirama 5 sampai 7 xylophone, marimba dan vibraphone kembali memainkan melodi pendek dan selanjutnya dibirama 7 sampai 9 semua alat musik perkusi melodis memainkan melodi pendek kembali secara bersama-sama (unisono) dengan menggunakan dinamika fortesimo.

Komposisi $\mathrm{C}$ ini terdiri dari 8 birama dengan menggunakan tada sukat/birama 4/4 yaitu setiap birama terdiri dariempat ketukan dan nilainadanya adalah seperempat. Sedangkan tanda temponya adalah allegro yang artinya cepat. Bentuk ompaosisi ini merupakan hasil adaptasi dari pola ritme dangdut 3 yakni terdiri dari part 1 diadaptasikan

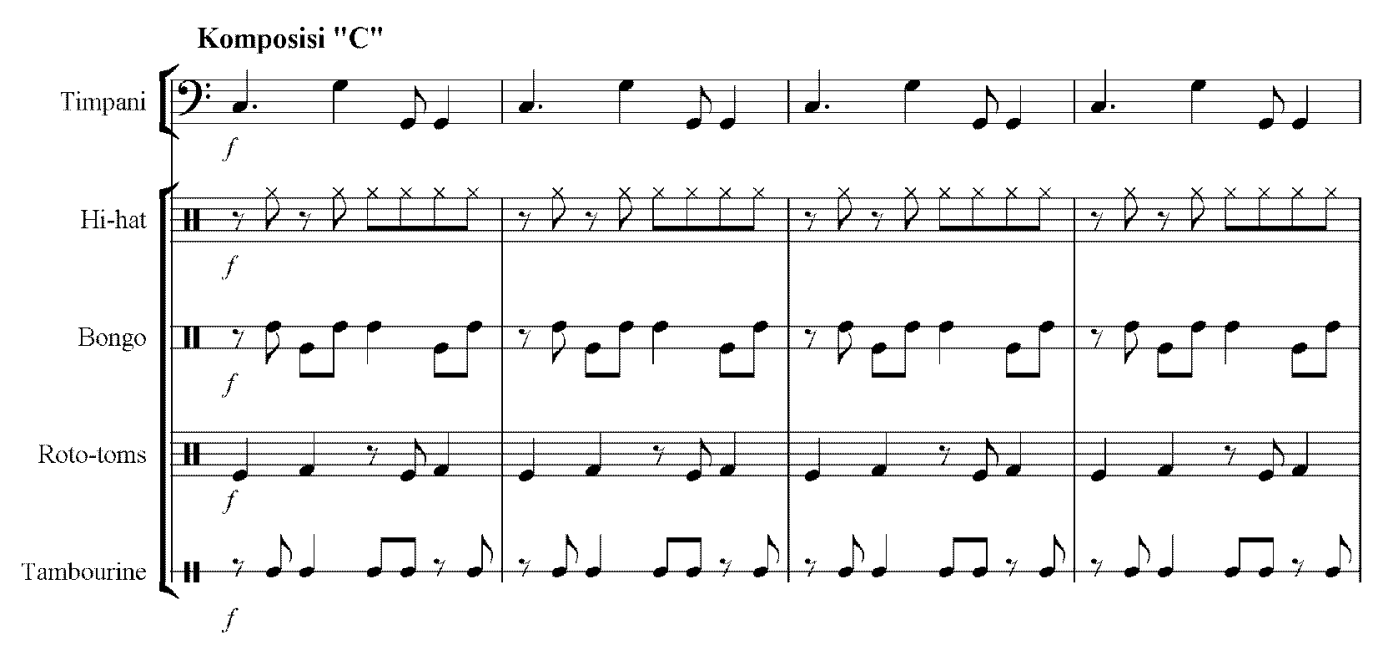




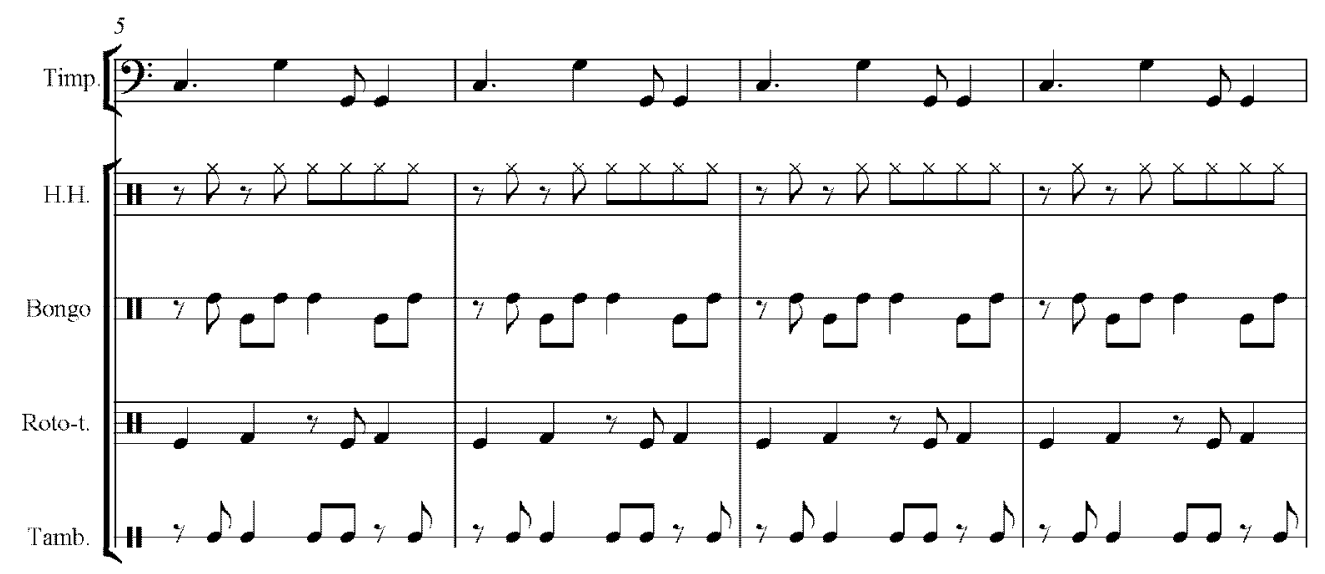

pada timpani, bentuk pola ritmenya dari birama 1 sampai dengan birama 8 sama dimainkan sama dan menggunakan dinamika fortesimo $(f)$ yang artinya keras, dan untuk part 2 diadaptasikan pada hi-hat, bentuk pola ritmenyan dari birama 1 sampai dengan birama 8 dimainkan sama dan dinamikanya juga menggunakan fortesimo $(f)$ yang artinya keras, kemudian pada part 3 diadaptasikan pada bongo, bentuk pola ritmenya dari birama 1 sampai dengan birama 8 dimainkan sama dan menggunakan dinamika fortesimo $(f)$ yang artinya keras, sedangkan part 4 dan 5 akan diadaptasikan pada roto-toms dan tambourine, bentuk pola ritmenya dari birama 1 sampai dengan birama 8 dimainkan sama dan dinamikanya menggunakan fortesimo (f). Komposisi C ini di kelompokkan menjadi 2 macam yaitu basic pulse (timpani, hihat dan tambourine) dan solo attack (bongo dan roto-tom).

Komposisi C1 terdiri dari 9 birama dengan menggunakan tanda sukat/birama $4 / 4$ yaitu setiap birama terdapat empat ketukan dengan nilai nada seperempatan. Tanda temponya adalah andante yang artinya lambat. Bentuk pola ritme pada komposisi $\mathrm{C} 1$ yaitu sama seperti bentuk pola

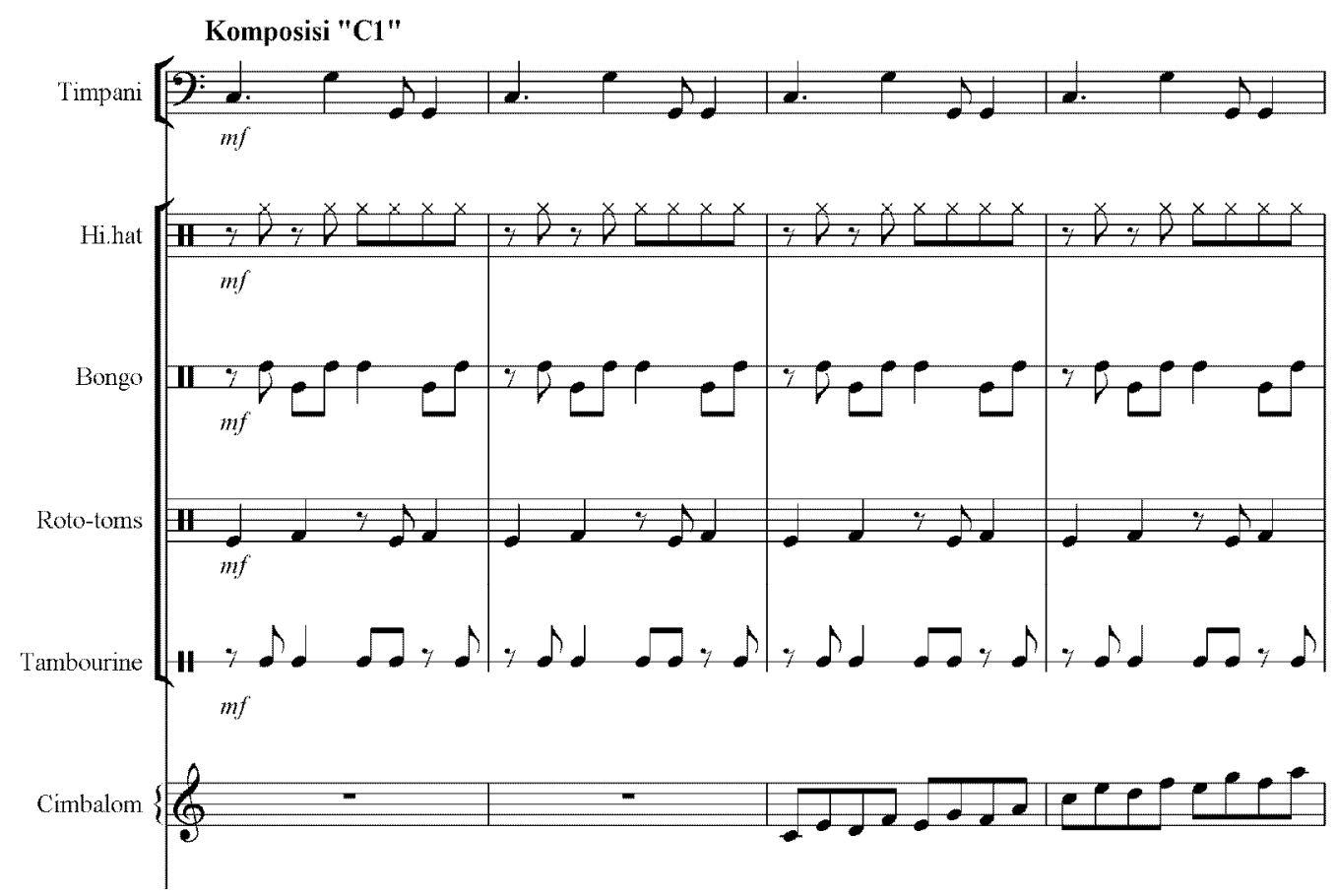



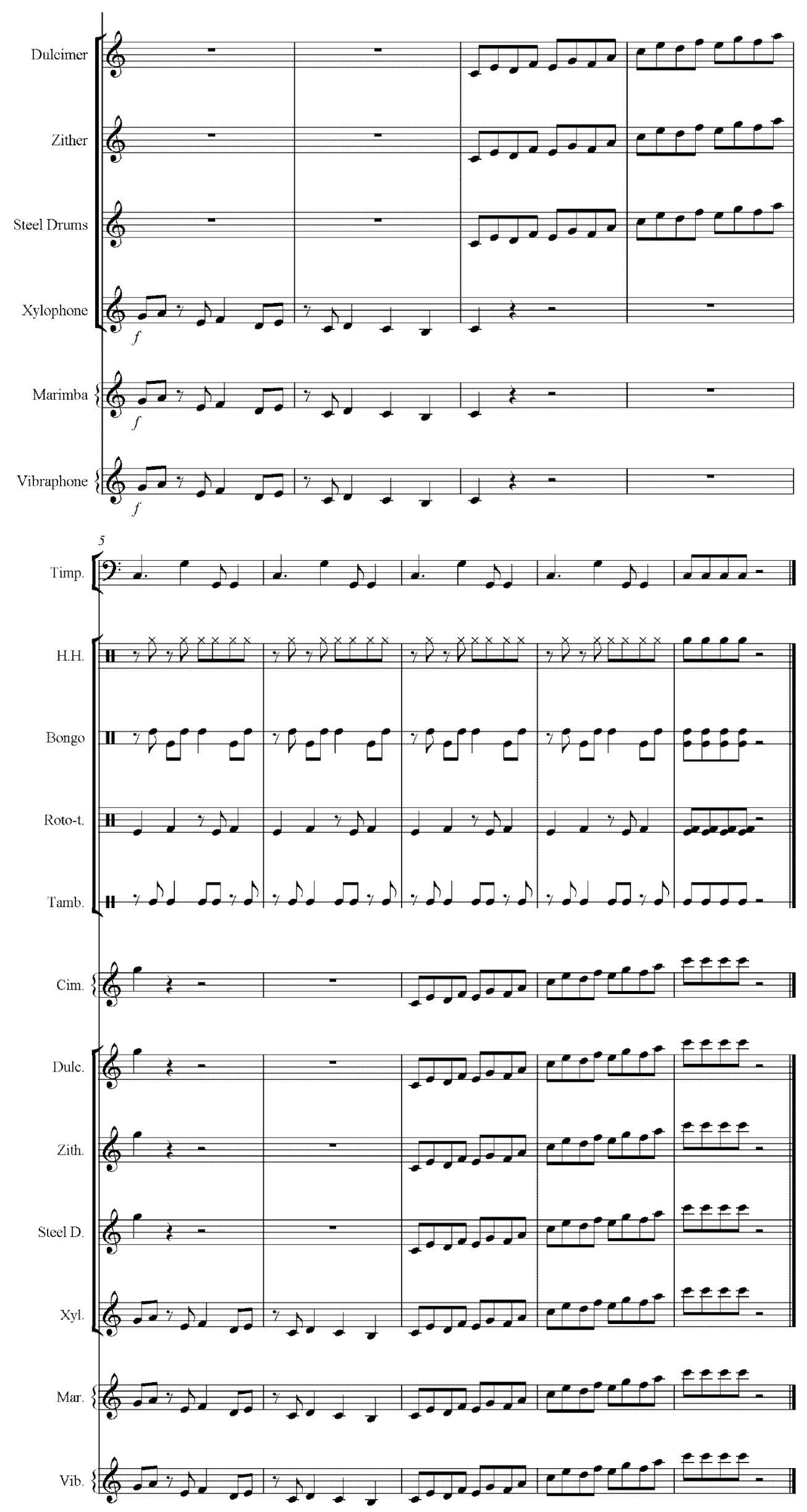
ritme pada komposisi $\mathrm{C}$ yakni birama 1 sampai 8 merupakan hasil adaptasi dari bentuk pola ritme dangdut 3 yakni untuk part 1 diadaptasikan pada timpani, dan part 2 diadaptasikan pada hi-hat, untuk part 3 diadaptasikan pada bongo, sedangkan untuk part 4 dan 5 masing-masing diadaptasikan pada roto-tom dan tambourine, dengan menggunakan dinamika mezzo forte (agak keras). Komposisi $\mathrm{C} 1$ selain menggunakan alatalat musik perkusi ritmis juga menggunakan alatalat perkusi melodis seperti cimbalom, dulcimer, zither, steel drum, xylophone, marimba dan vibraphone. Di birama 1 sampai 3 muncul melodi pendek dimainkan oleh xylophone, marimba dan vibraphone secara bersama-sama (unisono) dimainkan dengan keras (fortesimo), kemudian di birama 3 sampai 5 terdapat melodi baru yang dimainkan oleh cimbalom, dulcimer, zither dan steel drum secara bersama-sama (unisono) juga dimainkan dengan keras dan pada birama 5 sampai 7 xylophone, marimba dan vibraphone kembali memainkan melodi pendek, selanjutnya di birama 7 sampai 9 secara bersama-sama semua alat-alat musik perkusi melodis memainkan kembali melodi dengan dinamika fortesimo.

Komposisi D terdiri dari 8 birama dengan menggunakan tada sukat/birama 4/4 yaitu setiap birama terdapat empat ketukan dan masingmasing mempunyai nilai nada seperempatan. Komposisi ini menggunakan tanda tempo allegro yang artinya cepat. Bentuk pola ritme pada
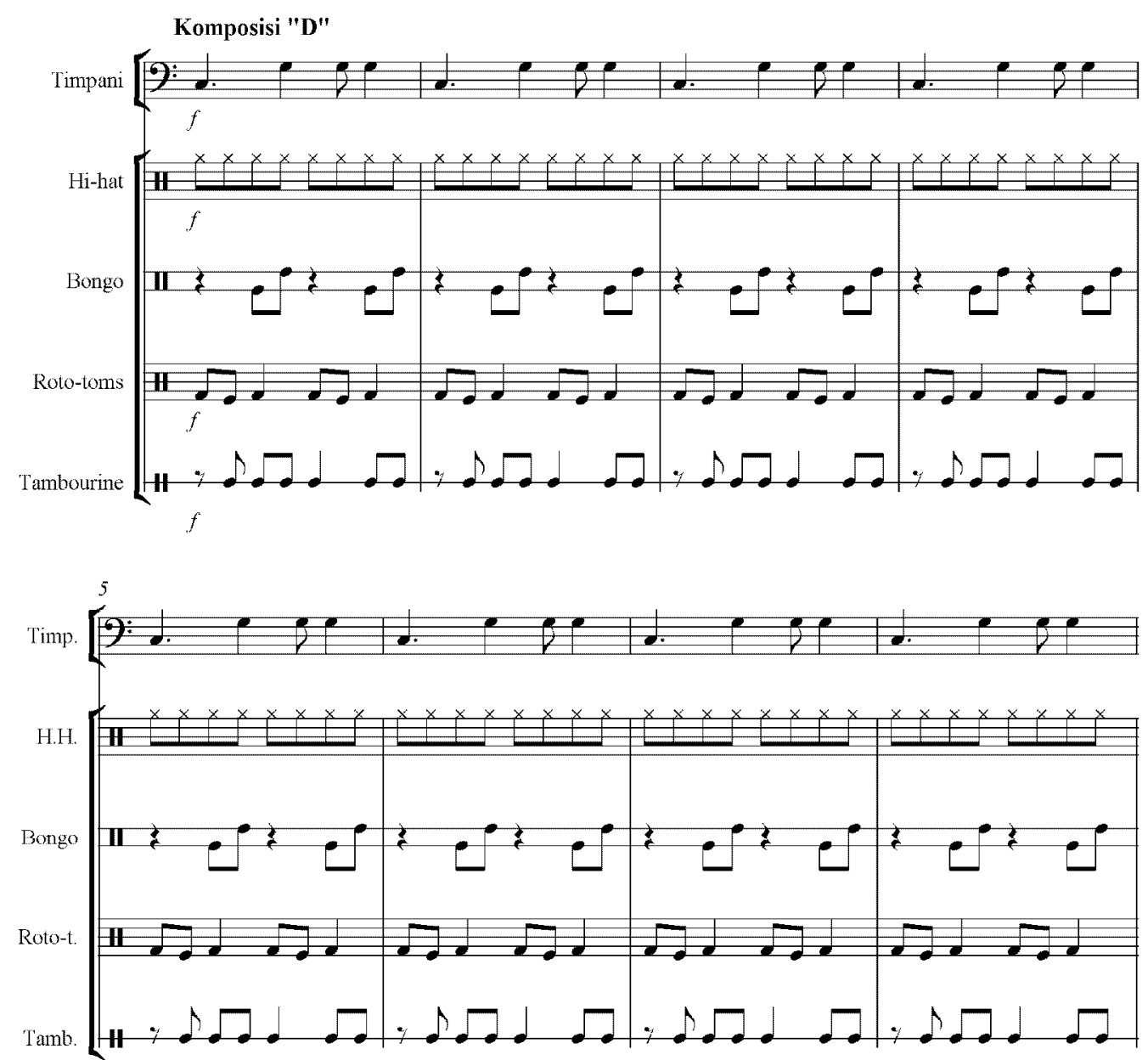
komposisi ini merupakan hasil adaptasi dari pola ritme dangdut 4 yakni terdidi dari part 1 diadaptasikan pada timpani, bentuk pola ritmenya dari birama 1 sampai dengan birama 8 dimainkan sama dan menggunakan dinamika fortesimo $(f)$ yang artinya keras, untuk part 2 diadaptasikan pada hi-hat, bentuk pola ritmenya dari birama 1 sampai dengan birama 8 dimainkan sama dan menggunakan dinamika fortesimo (f) yang artinya keras, kemudian part 3 diadaptasikan pada bongo, bentuk pola ritmenya dari birama 1 sampai dengan birama 8 dimainkan sama dan juga menggunakan dinamika fortesimo $(f)$ yang artinya keras, sedangkan untuk part 4 dan 5 masing-masing diadaptasikan pada roto-tom dan tambourine, bentuk pola ritmenya dari birama 1 sampai dengan birama 8 imainkan sama dan menggunakan dinamika fortesimo $(f)$ yang artinya keras. Untuk komposisi D ini dikelompokkan menjadi 2 macam yakni kelompok basic pulse ( timpani, hi-hat dan tambourine) dan solo attack (bongo dan roto-tom).

Komposisi D1 terdiri dari 9 birama dengan menggunakan tanda sukat/birama $4 / 4$ yaitu setiap birama terdapat empat ketukan dan masingmasing ketukan nilai nadanya adalah seperempat. Komposisi ini menggunakan tanda tempo allegro yang artinya cepat.

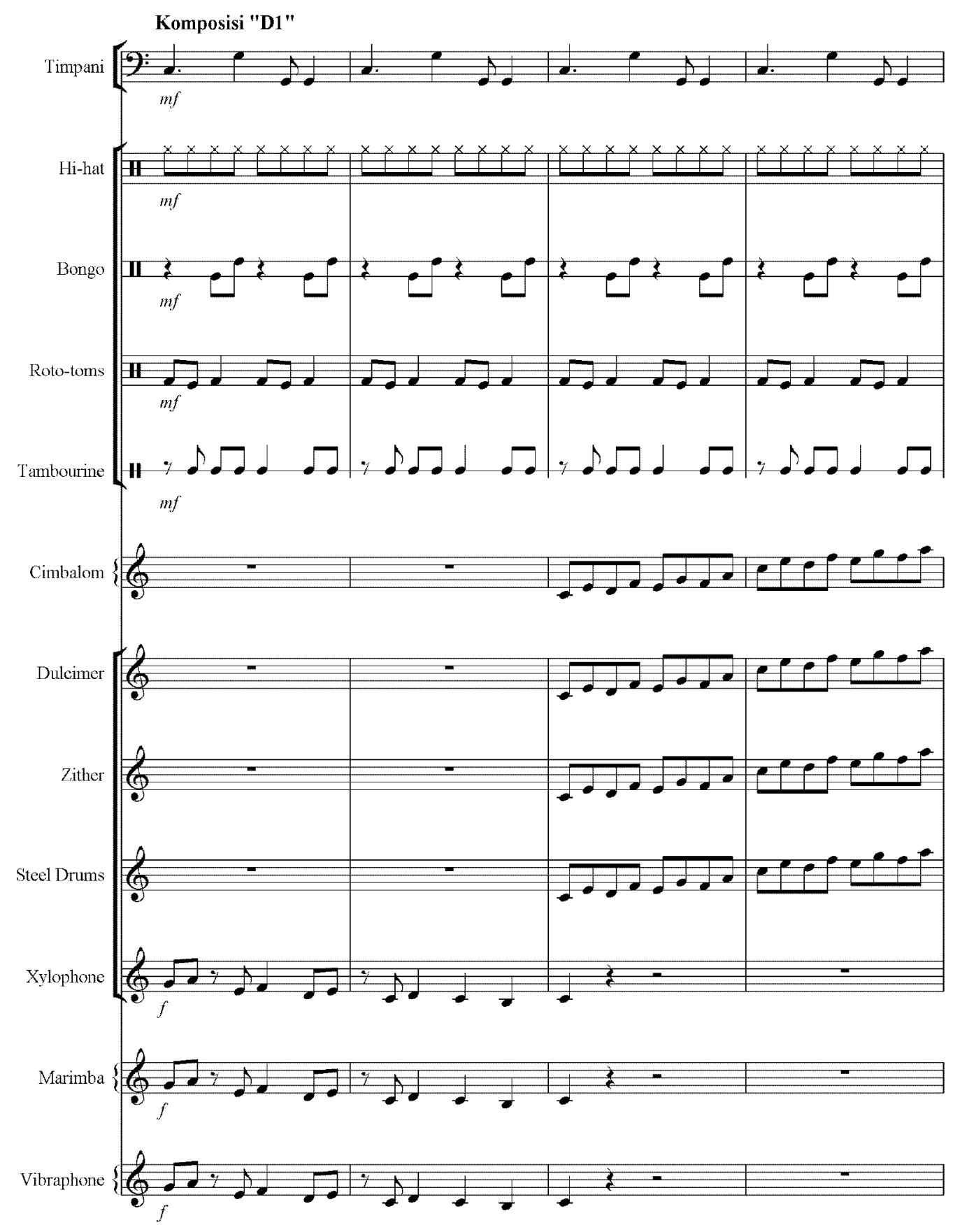



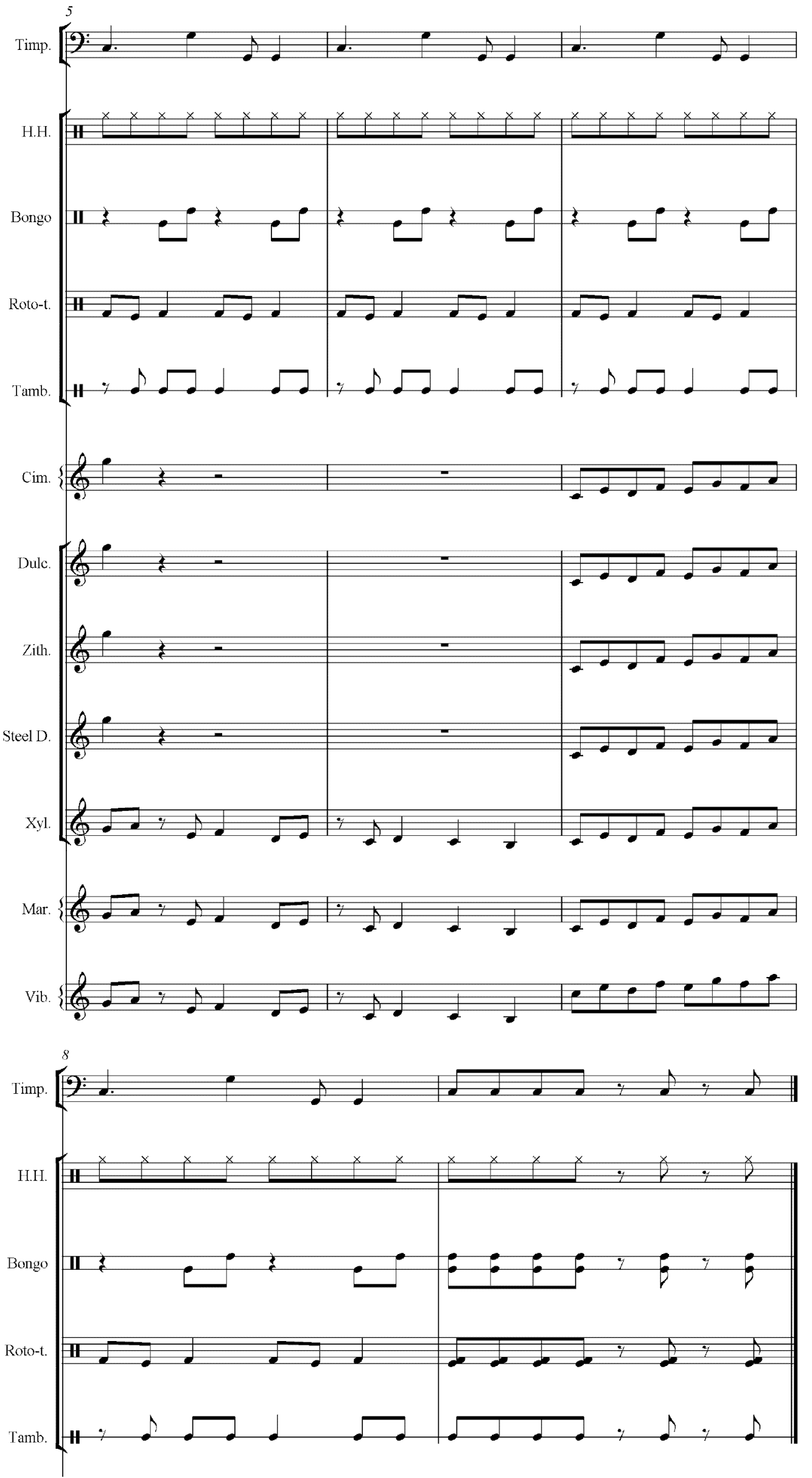


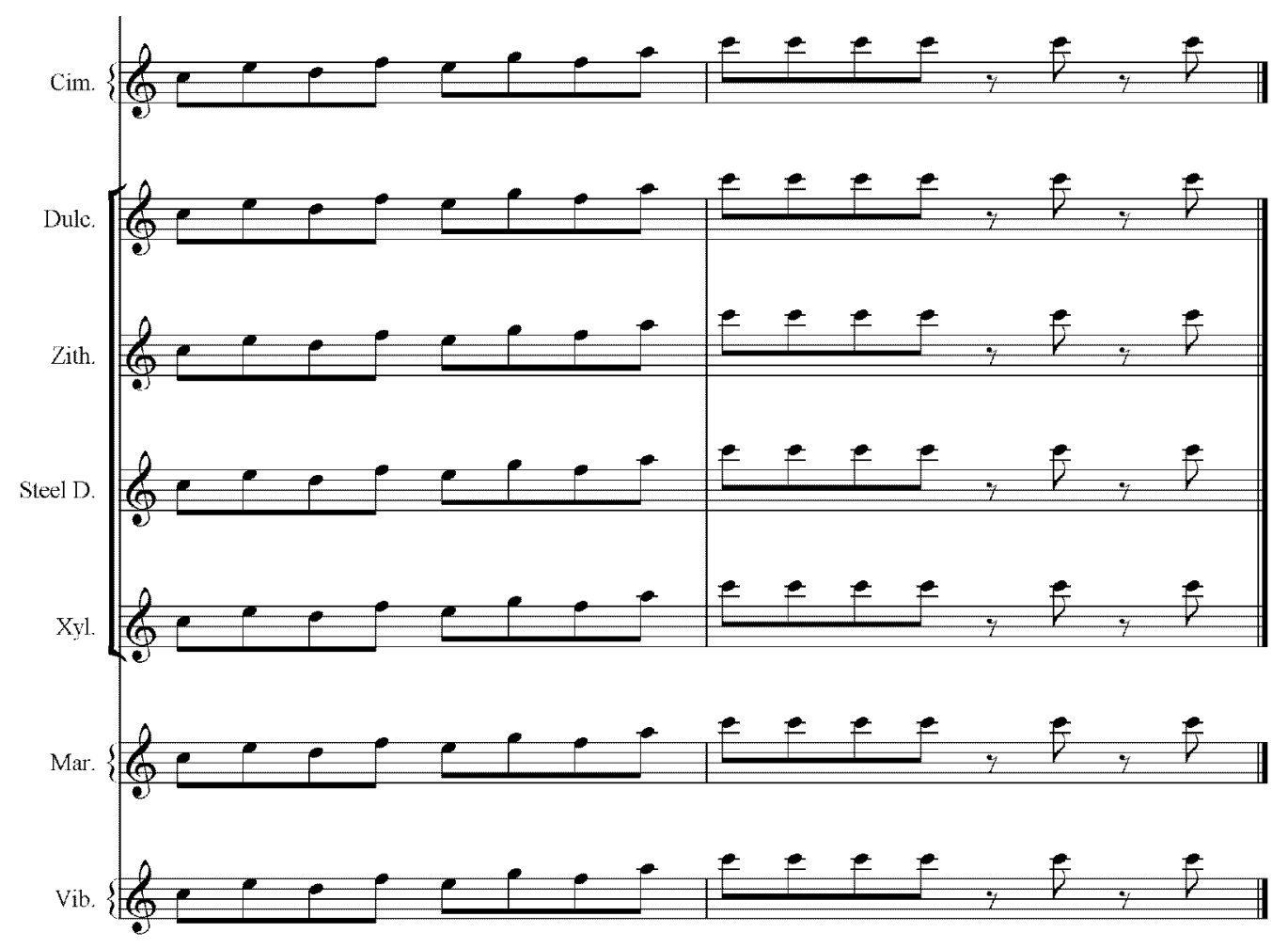

Bentuk pola ritme pada komposisi ini sama seperti komposisi D yakni birama 1 sampai 8 merupakan hasil adaptasi dari bentuk pola ritme dangdut 4 masing-masing part diadaptasikan pada 5 alat musikperkusi sepeti timpani, hi-hat, bongo dan roto-tom serta tambourine dengan menggunakan dinamika mezzo forte. Pada komposisi D1 selain menggunakan alat-alat perkusi ritmis juga menggunakan alt-alat perkusi yang bersifat melodis seperti cimbalom, dulcimer, zither, steel drum, xylophone, marimba dan vibraphone. Pada birama 1 sampai 3 muncul sebuah melodi pendek yang dimainkan oleh xylophone, marimba dan vibraphone secara bersama-sama (unisono) dan dimainan dengan keras, kemudian di birama 3 sampai 5 terdapat melodi baru secara bersama-sama yang dimainkan oleh cimbalom, dulcimer, zither dan steel drum juga dengan keras, selanjutnya dibirama 5 sampai 7 xylophone, marimba dan vibraphone kembali memainkan melodi secara bersama-sama, dan kemudian pada birama 7 sampai 9 secara bersama-sama sebuah melodi dimainkan oleh cimbalom, dulcimer, zither, steel drum, xylophone dan marimba serta vibraphone dengan menggunakan dinamika fortesimo.

\section{Penutup}

Musik merupakan salah satu cabang kesenian, hasil ciptaan dan pengembangan yang dilakukan oleh manusia. Tanpa disadari, kemampuan dan berbagai pengalaman musical yang terdapat pada individu dapat membentuk kehidupannya. Salah satunya adalah musik dangdut, merupakan hasil imajinasi manusia dalam mengekspresikan pengalaman jiwa dan penghayatannya melalui rasa estetis, serta bagian integral dari hakekat kehidupan manusia sendiri terutama dalam aspek berbudaya. Musik dangdut banyak sekali mengalami perkembangan dan perubahan. Perkembangan dan perubahan tersebut menyangkut hal-hal antara lain seperti peran, fungsi dan peralatannya. Sebagai hasil ciptaan manusia, musik dangdut banyak sekali keluar dari budaya aslinya seakan-akan berfungsi sebagai hiburan semata khususnya bagi para anak-anak muda. Sedangkan sesuai kemajuan teknologi peralatan yang digunakan dalam musik dangdut banyak menggunakan unsur-unsur elektronik, seperti gitar elektrik, bas gitar elektrik dan organ. Sesuai peran dan fungsinya keberadaan musik dangdud ditengah-tengah masyarakat begitu kuat khususnya dikalangan anak-anak muda, untuk itu perlunya dijaga dan dilestarikan agar tidak mudah punah.

Berkaitan dengan hal tersebut perancangan ini 
merupakan salah satu upaya dalam memecahkan permasalahan yang ada yakni melalui ungkapan dan penemuan bahwa komposisi musik yang menggunakan idiom-idiom musik dangdut akan membuahkan pengetahuan teoritis dan filisofi yang akan mendasari pemahaman estetika penciptaan baru yakni ansambel musik perkusi.

\section{Kepustakaan}

Blacking, John. 1974. Seberapa Musikalkah Manusia?, Terj.Victor Ganap. Yogyakarta: UPT Perpustakaan ISI Yogyakarta.

Blades, James. 1984. Percussion Instrument and Their History. London: Faber and Faber.

Brameld, Theodore. 1957. Cultural Foundation of Education An Interdiciplinary Exploration. New York: Green Wood Press.

Dean, Johnni. 1981. Latin New Wave-Latin Percassion. London: Chappel Mudic Ltd.

Djoharnurani, Sri, 1999. "Teks dan Konteks: Sumber Penciptaan" dalam Jurnal Seni, VII/ 02 Oktober 1999.

Gray, Cecil. 1847. The History of Music. New
York: Kegan Paul.

Janet, Wolff, 1993. The Social Production of Art. New York: New YorkUniversity Press.

Miller, Hugh. 1959. Introduction of Musik a Guide to Good Listening. New Mexico: Barnes \& Noble.

Kawakami, Genichi, 1975. Arranging Populer Music: A Practical Guide. Tokyo: Yamaha Music Foundation.

Stein, Leon. 1979. Structur and Style: The Study and Analisis of Music Form. New Jersey: Summy Birchard Music.

Sasongko Hari, M, 2007. "Dangdud sebagai eloquen Silences", dalam Ekspresi Jurnal Seni Vol 7, No. I, April.

Toni, Made, 2009. "Bius Sosial di Balik Goyang Dangdud”. dalam Basis No. 3 - 4 Juni.

Watanabe, Ruth.T. 1967. Intruduction to Music Research. New Jersey: Prentice-Hall Inc. 